\title{
The Economic Impact of COVID-19 Outbreak on the Agriculture Sector
}

\section{Dwia Aries Tina Pulubuhu ${ }^{1 *}$, Andi Alimuddin Unde², Suwandi Sumartias3, Sudarmo ${ }^{4}$, Seniwati ${ }^{5}$}

${ }^{1}$ Department of Sociology, Faculty of Social and Political Sciences, Universitas Hasanuddin, Indonesia.

2 Department of Communication, Faculty of Social and Political Sciences, Universitas Hasanuddin, Indonesia.

${ }^{3}$ Department of Communication, Faculty Social and Political Sciences, Padjadjaran University, Indonesia.

${ }^{4}$ Administration Public Department, Faculty Social and Political Sciences, Sebelas Maret University, Indonesia.

${ }^{5}$ International Relations Department, Faculty Social and Political Sciences, Universitas Hasanuddin, Indonesia.

* Corresponding author's e-mail: dwiatn@unhas.ac.id

How to Cite: Pulubuhu, D.A.T., Unde, A.A., Sumartias, S., Sudarmo., and Seniwati. (2020). The Economic Impact of COVID-19 Outbreak on the Agriculture Sector. Int. J. Agr. Syst. 8(1): 57-63

\begin{abstract}
The COVID-19 pandemic in Indonesia began to be confirmed in early February 2020, it affects many various economic sectors, including agriculture. The COVID-19 created challenges for socio-economic issues. This short note focuses on the impact of COVID-19 outbreak on the agricultural sector. The COVID-19 outbreak had a wide-ranging impact, so that agricultural commodities continued to decline. The government's call to not leave the house resulted in many farmers not doing their activities so that it has an impact on declining farmers' income. The field officers also could not optimally carry out their work as a result the development of farming was not optimal. Various efforts have been made by the government to support the agricultural sector such as building e-marketing and training in processing yields for farmers.
\end{abstract}

Copyright @ 2020 IJAS. All rights reserved.

Keywords:

COVID-19; Agricultural Sector; E-Marketing; Training

\section{Introduction}

The COVID-19 pandemic in Indonesia began to be confirmed in early February 2020, slowly but surely the number infected by this virus continues to grow every day and has not shown a graph of decline. Previously, the epicenter was in the city of Jakarta and its surroundings, until now there are three provinces that become the new epicenter, namely, East Java, West Java and South Sulawesi. COVID-19 pandemic not only discusses about many people who are infected, but also its effects on economic indicator such as poverty and unemployment. Center of Reform on Economics (Core) 
Indonesia estimated that the potential for additional open unemployment nationally is 4.25 million people with a mild scenario. Second, an additional 6.68 million people with a medium scenario. Third, an additional up to 9.35 million people with severe scenario. Based on government calculations, the number of unemployed throughout 2020 will increase 2.9 million people in the heavy scenario and 5.2 million people in the severe scenario. Based on these calculations, the open unemployment rate nationally in the second quarter of 2020 is expected to reach 8.2\% (mild scenario); 9.79\% with a medium scenario; and $11.47 \%$ with severe scenarios [1]. Therefore, the number of workers who lose their jobs will also cause social capital threats in people's lives. In addition, COVID-19 created challenges for socio-economic issues [2] low input for agriculture productivity and health care [3], economic impact of government interventions [3], social effect of pandemic [4], personal economic anxiety [5], social trust in the midst of pandemic crisis [5] and socio-economic vulnerabilities [6].

This section focuses on the impact of economic losses on the agriculture sector that occur as a result of epidemic outbreaks, which are expected to provide recommendations for policy makers in formulating steps and policies when experiencing an epidemic Covid-19. The segmentation analysis in this section divides the impact of economic losses on the epidemic into three levels of analysis, namely at the micro level, sector level, and macro level.

Economic impact analysis at the micro level refers to individuals in the community or a company. The behavior of actors at this level tends to be related to the level of risk of virus infection and economic value as a result of an epidemic situation. Directly, the impact of economic losses from epidemic outbreaks related to the allocation of resources is fully directed or invested in handling, controlling, and preventing epidemics. For example, company budgets will be allocated a lot for assistance in developing vaccines or anti-viral drugs and for the medical treatment of infected patients. In addition, various employment sectors or companies will experience problems related to labour supply. Workers in epidemic situations tend to be greatly reduced due to virus infection or as a result of work from home policies. Individual and company income tends to decline and can pose a threat of poverty, declining health status and public education as a long-term impact of the epidemic. Indirectly, an epidemic can cause a decrease in labour productivity.

This micro level becomes a crucial level also to be considered because mismatches or failure of steps taken by individuals or companies can lead to allocation of public funding will be directed more towards efforts to control the virus than to focus on maintaining social and economic stability at the micro level. In addition, the preferences and effectiveness of epidemic prevention and control measures in a company tend to affect the company's performance, investment activities and profits. Foreign investors tend to be able to easily withdraw their investment from a company if the prevention and control policy preferences taken by the company are considered ineffective [7]. This need a trust. Fukuyama said [8] if distrust is widespread in a lowtrust society, it will burden all forms of economic activity in the community and the state. This short note focuses on the impact of COVID-19 outbreak on the agricultural sector. 


\section{Impact of COVID-19 on Agricultural Sector: A Short Note}

The COVID-19 has an impact on agricultural sector, including horticultural activities and food crop farming activities are delayed due to a ban on going out of the house. Many farmers do not do their business because they have to be at home. This condition affects the aspect of maintaining agricultural crops which become poorly maintained and farmers are less able to control the attack of organisms that attack plants, ultimately these plants are difficult to market so that farmers' turnover is reduced. The field officers in the development of farming are not optimal at work so they cannot conduct routine monitoring.

Analysis of economic impacts at the sector level focuses on how the economic impact of the epidemic on certain sectors. In implementing prevention and control policies, the government tends to be easier to formulate at the sector level that will be in accordance with the specifications of each sector. Gong, Zhang, Yuan, \& Chen in their article explain the economic impact into three types of sectors, namely the main, secondary and tertiary sectors [7].

Another consequence is that many workers have lost their jobs. Many workers who have directly been in direct contact with consumers are now absent from work or are laid off by the company. Thus, the rate of unemployment at the time of the pandemic will increase. Companies should be able to condition their work behavior during the COVID-19 pandemic, for example by limiting working hours, providing health insurance for employees and providing incentives. So that companies and employees can benefit each other. Hanoatubun [9] explained in the case of Indonesia is a combination of two elements that occur simultaneously, where the external elements in the form of financial panic and the weakness of the national economy, both the banking sector and the real. These two factors affect each other where when external shocks arise, a weak national economy is easily susceptible to negative impacts so that turmoil that occurs in a short time turns into an economic crisis that occurs today that is felt by our country. If the problem of job loss has not yet been resolved, the poverty rate in Indonesia will also continue to increase and will have an impact on people's reduced purchasing power. Restrictions in trading have also been tightened, there are no selling activities in the crowd to reducing spread of the coronavirus. As a result, traders do not have a steady income because the community must continue to meet their daily needs.

The main sector is a sector that focuses on international trade, agriculture and logistics. In the agriculture sector, there tends to be a decrease in the availability of labour and the productivity of the workforce itself. As a long-term consequences without responsive and appropriate handling can cause a food crisis, for example in Ghana when the Ebola epidemic occurred in 2014 with losses of coffee and rice production which decreased by $50 \%$ and until the domestic food crisis occurred. Characteristics of viruses that are easily spread from human to human or from animal to human greatly affect the economy, including the main sectors. Media for spreading viruses through animals can cause a drastic decrease in demand for animals on the market because people will avoid consuming these animals. This condition can affect the export-import trade of these animals between countries. For example, the 2009 H1N1 epidemic caused a drastic reduction in pork exports due to one medium of transmission of the H1N1 virus, namely from pigs to humans. In addition to decreasing the quantity of animal meat export media spread by viruses due to decreased demand, countries then tend to apply trade restriction on imported commodities originating from epidemic 
countries [7]. The agricultural sector in Indonesia experiences shortages of stocks and rising commodity prices, while on the other hand consumer demand is high. The marketing system was also hampered due to the call from the government not to travel far and a limited transportation system. This condition causes the quality of agricultural commodities to be sold to be damaged.

The secondary sector is a sector that focuses on manufacturing. This manufacturing sector also consists of various sub-sectors with different specifications. This makes the economic impact felt in each sub-sector quite different. For sub-sectors in the biotechnology sector, stock prices have risen. This is as a result of increasing demand for products related to photocatalyst or nano-technology, such as masks. However, the hotel industry has decreased dramatically. This is due to changes in preference behavior of individuals who no longer make many visits or vacations so that not many consumers make transactions with the hotel industry [7]. As a result, agricultural commodities that are usually sent for the needs of hotel guests are also reduced. Finally, the impact on farmers' income continues to decrease.

Social distancing is one of the calls from President Jokowi to minimize COVID-19. The President also asked the public for work from home (WFH). In addition, working from home-which smart technologies facilitate-is likely to become a significantly more prominent feature of economic activity [10]. This appeal is supported by all Local Governments in Indonesia. Another appeal is the temporary closure of all tourist attractions, providing restrictions on public transportation hours and some companies must stop office activities replaced by WFH. This policy has a negative impact on hotel occupancy. Many people do not leave the house and cancel their travel schedules. Companies or offices change the agenda of offline meetings online via teleconferences conducted from their respective homes. Many events, exhibitions and weddings at hotels were postponed and even cancelled in order to prevent the outbreak of the COVID-19 virus. These policies resulted in a drastic reduction in the number of hotel guests so that some hotels had to close or lay off. Hotels that usually receive supplies from local agricultural commodities will also be reduced and even tend to be stopped temporarily.

The tertiary sector is a sector that focuses on the demand side as a result of outbreaks and the prevention and control policies that are implemented. Countries tend to implement a policy of restriction of movement as an effort to minimize the spread of the virus. One of the policies that can be applied is isolation and quarantine. Thus, the activity outside the home of people will be greatly decreased, except for important needs, such as food shopping. The service industry, restaurants, hotels, airlines, and retail tend to be affected by the policy of having to close their industries temporarily. Even without closing, consumer demand for them will also decrease. This will lead to a decline in the stock prices of these industries, a decline in the country's GDP, a break in the capital chain, a decline in government fiscal revenues, to the exit of several companies or businesses from the market due to not being able to withstand the impact of the economic losses experienced. The intensity and extent of the impact of the loss from this sector depends very much on the duration of the epidemic and the relevance of the prevention and control policies adopted [7]. The number of closed restaurants has an impact on agricultural commodities because some prices of agricultural products have increased due to the lack of these commodities on the market. 
Analysis of the impact of economic losses at the macro level refers to impacts in the scope of countries, regions, to the global. If more than one country in an area experiences an epidemic, then its spread tends to spread to various countries in the region. This drives the spill over effect to regional coverage. Disruption or impediments to economic growth as a result of epidemics on two or more countries in a region will cause disruptions and obstacles to economic growth in the region. This happens a lot in the case of foreign investment where foreign investors tend to hesitate to invest in areas that have epidemics. In addition, the cross-border tourism and tourism sector in an area where an epidemic country is in decline is due to the preference of consumers not to visit or travel to the region because the potential for contracting the virus is also large. For example, the 2015 Ebola epidemic that struck three countries in Western Africa resulted in the accumulation of economic losses in the African region to more than $\$ 500$ billion [7].

Gong et al further explained in their article that economic factors could be taken into consideration in taking epidemic prevention and control measures. The important thing in maximizing the effectiveness of handling epidemics is to classify preventive and control measures that have been applied so that they can become a reference for future steps. Preventive measures are divided into two, namely the adaptive steps undertaken in recovery after the epidemic has passed to reduce the prolonged impact of the epidemic and the eradication steps taken to stop the center or which is the source of the epidemic. The control measures are also divided into two, namely drug control related to the development of vaccines and anti-viral drugs, and non-drug control which is a step of public control and prevention. Travel restriction, family quarantine, isolation, school closure, to social distancing are examples of prevention and control measures to the public. This is because viruses that are easily transmitted through human contact so that restrictions on facilities or activities that facilitate the mobilization and gathering of humans in massive numbers are applied. In addition, the detection capabilities at the hospital should also be considered to be able to track the number and extent of virus distribution [7].

In implementing a policy, the government tends to use several methods in formulating steps or policies. This method uses cost and benefit analysis and depends on the speed of the spread of the virus and the level of death caused by the epidemic. The policy evaluation method is divided into three methods. First, there are methods based on epidemiology of the spread of the virus and adaptation of the SIR (Susceptible, Incentive, Removed) model. This method uses numerical simulations similar to scenarios for spreading viruses so this method tends to be scientific. This method is effective in policies that target the minimization and termination of the spread of the virus, but this method does not consider much economic and social factors. For example, travel restriction and school closure policies are effective in minimizing the number of people infected, but at the same time they cause economic losses as discussed earlier. The policy does not have a significant positive impact, so coordination and combination with other policies also need to be carried out. Second, the method that considers the minimum cost that focuses on the economic impact of the policies implemented. This method can provide an illustration related to how much the costs incurred from each policy. For example, the Ebola epidemic in 2014 can be divided into four policy target situations, namely people who recover and receive treatment, patients who die after receiving treatment, people who recover and receive extensive care, and patients who die after receiving extensive care. The result, namely for the case of people who recovered costs about $\$ 912$ per capita, while for the case of 
patients who died cost around \$ 18,929 per capita. Third, it is a method that considers how an individual's response is based on drinking costs. This method considers that individual response plays an important role because it greatly influences the rate of spread of the virus. In addition, individual responses in the form of changes in consumption behaviour and panic can lead to higher costs, especially for public prevention and control and cause large economic losses if individual responses cannot be controlled [7]. Therefore, the government develops e-marketing and provides training that can improve agricultural product processing skills. The government will also conduct regular monitoring to find out the transparency of agricultural stock data and hold a low-cost market that sells agricultural products.

\section{Conclusion}

The Coronavirus Disease 2019 (COVID-19) outbreak became a pandemic and has attacked all sectors including the agricultural sector. Food commodities become expensive because agricultural products also continue to decrease. Hotels, restaurants and other industries which usually supply agricultural commodities continue to decrease due to the reduced number of guests or consumers who cancel their shows. Various solutions have been made by the government in helping to improve the agricultural sector such as conducting coaching in areas of agricultural centers.

\section{Acknowledgements}

This research was funded by Ministry of Research, Technology and Higher Education with Decree Number 172/SP2H/LT/DPRM/2019 dated March 11, 2019 and Agreement/Contract Number 2042/UN4.21/PL.00.00/2019 dated April 24, 2019.

\section{References}

[1] A A Mustami, 2020 Pengangguran akibat Covid-19 bisa melebihi hitungan pemerintah Jakarta: kontan.co.id.

[2] Nicola M et al., 2020 The socio-economic implications of the coronavirus pandemic (COVID-19): A review Int. J. Surg. 78 p. 185-193.

[3] Pratap Singh R Kataria R and Ul Haq M F, 2020 Letter to the editor in response to: COVID-19 pandemic and challenges for socio-economic issues, healthcare and national programs in India (Gopalan and Misra) Diabetes Metab. Syndr. Clin. Res. Rev. 14, 5 p. 841-842.

[4] Ashraf B N, 2020 Economic impact of government interventions during the COVID-19 pandemic: International evidence from financial markets J. Behav. Exp. Financ. 27 p. 100371.

[5] Mann F D Krueger R F and Vohs K D, 2020 Personal economic anxiety in response to COVID-19 Pers. Individ. Dif. p. 110233.

[6] Mikolai J Keenan K and Kulu H, 2020 Intersecting household level health and socio-economic vulnerabilities and the COVID-19 crisis: An analysis from the UK SSM - Popul. Heal. p. 100628.

[7] Gong B Zhang S Yuan L and Chen K Z, 2020 A balance act: minimizing economic loss while controlling novel coronavirus pneumonia J. Chinese Gov. 0, 0 p. 1-20.

[8] Fukuyama F, 1995 Trust: The social virtues and the creation of prosperity 99 Free press New York, NY. 
[9] Hanoatubun S, 2020 Dampak Covid-19 terhadap Prekonomian Indonesia EduPsyCouns J. Educ. Psychol. Couns. 2, 1 p. 146-153.

[10] Prettner K and Bloom D E, 2020, Chapter 8 - Peering into the future: long-run economic and social consequences of automation; with an epilogue on COVID19, K. Prettner and D. E. B. T.-A. and I. M. C. Bloom, Eds. (Academic Press), p. 209-221.

[1] A A Mustami, 2020 Pengangguran akibat Covid-19 bisa melebihi hitungan pemerintah Jakarta: kontan.co.id.

[2] Nicola $\mathrm{M}$ et al., 2020 The socio-economic implications of the coronavirus pandemic (COVID-19): A review Int. J. Surg. 78 p. 185-193.

[3] Pratap Singh R Kataria R and Ul Haq M F, 2020 Letter to the editor in response to: COVID-19 pandemic and challenges for socio-economic issues, healthcare and national programs in India (Gopalan and Misra) Diabetes Metab. Syndr. Clin. Res. Rev. 14, 5 p. 841-842.

[4] Ashraf B N, 2020 Economic impact of government interventions during the COVID-19 pandemic: International evidence from financial markets J. Behav. Exp. Financ. 27 p. 100371.

[5] Mann F D Krueger R F and Vohs K D, 2020 Personal economic anxiety in response to COVID-19 Pers. Individ. Dif. p. 110233.

[6] Mikolai J Keenan K and Kulu H, 2020 Intersecting household level health and socio-economic vulnerabilities and the COVID-19 crisis: An analysis from the UK SSM - Popul. Heal. p. 100628.

[7] Gong B Zhang S Yuan L and Chen K Z, 2020 A balance act: minimizing economic loss while controlling novel coronavirus pneumonia J. Chinese Gov. 0, 0 p. 1-20.

[8] Fukuyama F, 1995 Trust: The social virtues and the creation of prosperity 99 Free press New York, NY.

[9] Hanoatubun S, 2020 Dampak Covid-19 terhadap Prekonomian Indonesia EduPsyCouns J. Educ. Psychol. Couns. 2, 1 p. 146-153.

[10] Prettner K and Bloom D E, 2020, Chapter 8 - Peering into the future: long-run economic and social consequences of automation; with an epilogue on COVID19, K. Prettner and D. E. B. T.-A. and I. M. C. Bloom, Eds. (Academic Press), p. 209-221. 